\title{
Pengembangan Bahan Ajar Fisika SMA Berbasis Learning Cycle (LC) $3 E$ Pada Materi Pokok Teori Kinetik Gas dan Termodinamika
}

\author{
Musanni $^{1}$, Susilawati ${ }^{2}$, Aos Santosa Hadiwijaya ${ }^{3}$ \\ Program Studi Magister Pendidikan IPA Universitas Mataram ${ }^{1,2,3}$ \\ SMA Negeri 5 Mataram $^{1}$
}

sani.musfis@gmail.com, susilawatihambali@yahoo.co.id, aos_santosa@yahoo.com

\begin{abstract}
ABSTRAK
Penelitian ini bertujuan untuk mengembangkan bahan ajar fisika SMA berbasis learning cycle $(L C) 3 E$ pada materi pokok teori kinetik gas dan termodinamika. Penelitian dilakukan dengan menggunakan pendekatan $\mathrm{R} \& \mathrm{D}$ yang diadaptasi dari Borg \& Gall yang meliputi tahap studi pendahuluan, tahap pengembangan, dan tahap pengujian. Pada tahap studi pendahuluan dilakukan analisis hasil studi literatur dan studi lapangan sehingga dihasilkan rumusan kebutuhan bahan ajar fisika. Tahap pengembangan dilakukan dengan penyusunan prototype bahan ajar dan perangkat pendukungnya, validasi ahli, evaluasi dan perbaikan, uji coba terbatas, dan evaluasi dan penyempurnaan. Tahap pengujian dilakukan di SMAN 5 Mataram yang bertujuan untuk mengetahui keefektifan produk bahan ajar dalam meningkatkan hasil belajar fisika siswa dan mengetahui kelayakan produk tersebut. Pengujian dilakukan menggunakan metode eksperimen pretest-posttest control group design yang melibatkan dua kelas sebagai sampel yaitu kelas XI IPA 2 dengan 33 siswa sebagai kelas eksprimen dengan bahan ajar baru dan kelas XI IPA 5 dengan 32 siswa sebagai kelas kontrol dengan bahan ajar lama. Keefektifan bahan ajar dianalisis menggunakan uji anakova pada taraf signifikansi $5 \%$. Dari analisis anakova diperoleh $F_{\text {hitung }}=7,54>F_{\text {tabel }}=4,00$ yang menunjukkan bahwa bahan ajar fisika berbasis learning cycle lebih efektif untuk meningkatkan hasil belajar fisika siswa. Tanggapan siswa terhadap produk bahan ajar diperoleh melalui angket dan dianalisis secara deskriptif. Hasil analisis memberikan gambaran bahwa baik aspek isi, kebahasaan, penyajian, dan kegrafikaan memperoleh tanggapan dengan rata-rata penilain pada kategori tinggi, sehingga produk ini layak digunakan dalam pembelajaran fisika pada materi pokok teori kinetik gas dan termodinamika di tingkat SMA.
\end{abstract}

Kata kunci: Pengembangan bahan ajar, learning cycle, teori kinetik gas dan termodinamika

\begin{abstract}
This study aims to develop teaching materials based high school physics learning cycle ( LC ) $3 \mathrm{E}$ in the subject matter and thermodynamics kinetic theory of gases. The study was conducted using the R \& D approach is adapted from Brog and Gall which includes the preliminary study stage, stage of development, and testing phases. At this stage of the analysis of the results of a preliminary study conducted literature studies and field studies so that the resulting formulation needs teaching materials physics. Stage of prototype development was done with the preparation of teaching materials and support tools, expert validation, evaluation and improvement, limited testing, and evaluation and improvement. Phase of testing was conducted at SMAN 5 Mataram which aims to determine the
\end{abstract}


effectiveness of the products teaching materials in improving learning outcomes physics students and determine the feasibility of the product. Tests carried out using an experimental method pretest - posttest control group design involving two classes as the sample that is class XI Science 2 class with 33 students as experiment with new teaching materials and class XI IPA 5 with 32 students as the control class with the old teaching materials. The effectiveness of teaching materials was analyzed using Anacova test at a significance level of $5 \%$. Anacova obtained from the analysis of $F_{\text {count }}=7.54>F_{\text {table }}=$ 4.00 which indicates that the physics - based teaching materials more effective learning cycle to improve student learning outcomes physics. The response of students to the teaching material products obtained through questionnaires and analyzed descriptively. The results of the analysis suggests that both aspects of the content, language, presentation, and graphical obtain responses with an average assessment in the high category, so that the product is fit for use in the teaching of physics in the subject matter kinetic theory of gases and thermodynamics at the high school level.

Keywords: Development of teaching materials, learning cycle, the kinetic theory of gases and thermodynamics

\section{Pendahuluan}

Ilmu fisika merupakan ilmu yang paling fundamental diantara ilmu pengetahuan alam, karena ilmu fisika dapat memberikan kerangka konseptual dasar dan teoritis terhadap perkembangan teknologi dan ilmu pengetahuan alam lainnya. Oleh karena itu, ilmu fisika telah secara khusus diberikan di tingkat Sekolah Menengah Atas (SMA).

Mata pelajaran fisika di SMA merupakan salah satu mata pelajaran yang dirasakan sulit, tidak menarik, tidak menyenangkan, bahkan ditakuti oleh siswa. Hal ini merupakan akibat dari pelaksanaan pembelajaran fisika masih bersifat konvensional yaitu berpatokan pada buku (texbook oriented) dan terpusat pada guru (teacher centred). Fisika dibagun berdasarkan langkah-langkah ilmiah melalui analisis fakta-fakta sehingga menjadi konsep, prinsip, hukum dan sampai pada teori. Oleh sebab itu pembelajaran fisika seharusnya mengukuti langkah-langkah ilmiah melalui pemanfaatan model-model pembelajaran yang berdasarkan pada penemuan dan berpusat pada siswa (student centred).

Salah satu model pembelajaran yang menekankan pada penemuan dan bersifat student centred adalah model Learning Cycle $(L C)$. Learning Cycle adalah suatu model pembelajaran yang berlandaskan pada teori belajar konstruktivisme. Teori ini menyatakan bahwa anak membangun sendiri pengetahuan dari pengalamannya sendiri ketika berinteraksi dengan lingkungannya Trianto (2007). Berdasarkan pandangan Piaget dalam Trianto (2007), pengetahuan datang dari tindakan, perkembangan kognitif sebagian besar bergantung pada seberapa jauh anak aktif berinteraksi dengan lingkungannya. Dalam hal ini peran guru adalah sebagai fasilitator dan buku sebagai pemberi informasi. 
Model pembelajaran Learning Cycle 3E dikembangkan oleh Karplus pada tahun 1977 (Purwoko, 2009). Model pembelajaran ini terdiri dari tiga fase, yaitu ekplorasi (exploration), pengenalan konsep (concept introduction), dan aplikasi konsep (concept application).

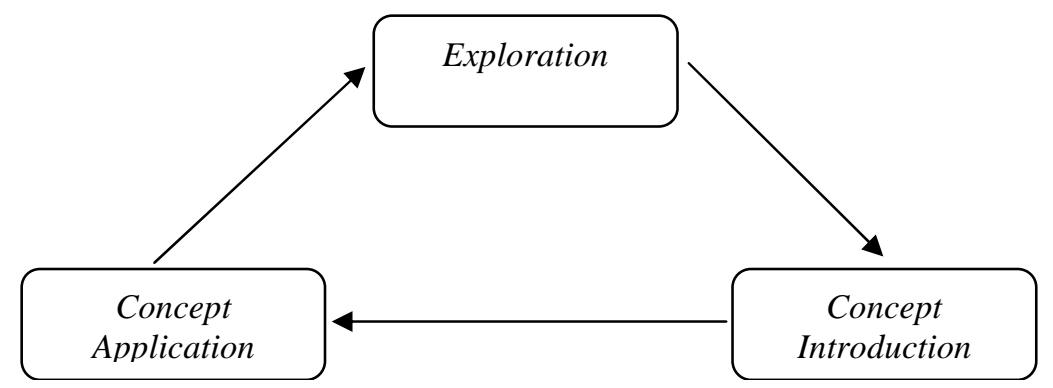

Gambar 1: Model learning cycle 3 fase menurut Karplus (1977)

Fase eksplorasi bertujuan untuk mengetahui pengetahuan awal siswa. guru menyajikan fakta atau fenomena yang berkaitan dengan konsep yang akan diajarkan melaui bahan ajar yang disajikan. Pembelajaran dimulai dengan pernyataan berupa suatu pertanyaan sebab. Siswa diminta untuk merumuskan jawaban-jawaban (hipotesishipotesis) yang mungkin terhadap pertanyaan itu. Selanjutnya siswa diminta untuk menurunkan konsekuensi-konsekuensi logis dari hipotesis-hipotesis ini, merencanakan, serta melakukan percobaan untuk meguji hipotesis-hipotesis itu. Tahap ini juga dapat dilakukan dengan penelusuran informasi oleh siswa melalui berbagai sumber belajar yang lain.

Pada fase pengenalan konsep dilakukan analisis hasil eksplorasi fakta yang diperoleh dari fase eksplorasi yang menyebabkan beberapa hipotesis ditolak, sedangkan yang lain diterima. Pada saat ini siswa digiring untuk menuju keseimbangan baru, suatu proses yang menggambarkan interaksi antara informasi baru dan pengetahuan awal (preexisting knowledge) melalui telaah pustaka, bahan ajar, dan berdiskusi.

Fase pengenalan konsep memberikan kesempatan bagi siswa untuk menerapkan pengetahuan dan konsep barunya pada penomena-penomena yang relevan melalui kegiatan-kegiatan seperti problem solving atau melakukan percobaan lebih lanjut. Penerapan konsep dapat meningkatkan pemahaman dan hasil belajar dan motivasi belajar, karena siswa mengetahui penerapan nyata dari konsep yang mereka pelajari.

Model pembelajaran learning cycle $3 E$ memiliki keunggulan dapat digunakan untuk menjelaskan konsep-konsep yang abstrak (Purwoko, 2009). Dengan demikian model ini cukup relevan apabila diterapkan pada pembelajaran fisika, karena sebagian materi 
fisika terdiri dari konsep-konsep yang abstrak (Fikri, 2012). Salah satu contoh materi fisika yang bersifat abstrak adalah teori kinetik gas dan termodinamika. Untuk membantu guru dan siswa dalam proses pembelajaran, materi-materi fisika yang bersifat abstrak ini dapat di kemas dalam bentuk media berupa bahan ajar yang mengacu pada fase-fase model pembelajaran learning cycle $3 E$.

Bahan ajar merupakan bagian penting dalam pelaksanaan pendidikan di sekolah. Maryani (2011), mendefinisikan bahan ajar sebagai seperangkat materi yang disusun secara sistematis baik tertulis maupun tidak sehingga tercipta lingkungan/suasana yang memungkinkan siswa untuk belajar. Dengan bahan ajar memungkinkan siswa dapat mempelajari suatu kompetensi atau kompetensi dasar secara runtut dan sistematis sehingga secara akumulatif mampu menguasai semua kompetensi secara utuh dan terpadu. Hernawan (2010), menegaskan bahwa bahan ajar sangat menetukan keberhasilan pendidikan siswa dalam proses pembelajaran di sekolah, oleh karena itu bahan ajar yang baik dan bermutu selain menjadi sumber pengetahuan yang dapat menunjang keberhasilan belajar siswa, juga dapat membimbing dan mengarahkan proses pembelajaran ke arah proses pembelajaran yang bermutu.

Bahan ajar memiliki berbagai bentuk. Balai Pengembang Teknologi Pendidikan, mengelompokkan bahan ajar menurut jenisnya menjadi empat yaitu: (1) bahan cetak (printed) seperti: handout, buku, modul, lembar kerja siswa, brosur, leaflet, wallchart, foto/gambar, model/maket; (2) Bahan ajar dengar (audio) seperti: kaset, radio, piringan hitam, dan compact disk audio (3) Bahan ajar pandang dengar (audio visual) seperti: video compact disk dan film; (4) Bahan ajar interaktif (interacitive teaching material) seperti compact disk interaktif (Depdiknas, 2007).

Bahan ajar cetak merupakan bahan ajar yang bentuk dan penyusunannya cukup sederhana, sehingga sebagai pengembang pemula sebaiknya memulai dengan pengembangan bahan ajar jenis ini. Kemp dan Dayton (1985) dalam Prastowo (2011), mendefinisikan bahan ajar cetak (printed) sebagai sejumlah bahan yang disiapkan dalam kertas yang dapat berfungsi untuk keperluan pembelajaran atau penyampaian informasi.

Buku merupakan salah satu bentuk bahan ajar cetak. Surahman dalam Prastowo (2011), mengelompokkan buku menjadi empat jenis yaitu: (1) buku sumber adalah buku yang biasa dijadikan rujukan, referensi, dan sumber untuk kajian ilmu yang lengkap; (2) buku bacaan adalah buku yang hanya berfungsi untuk bahan bacaan saja, misalnya: cerita, legenda, novel dan lain sebagainya; (3) buku pegangan adalah buku yang biasa dijadikan 
pegangan guru atau pengajar dalam melaksanakan proses pembelajaran; (4) buku bahan ajar adalah buku yang disusun untuk proses pembelajaran dan berisi bahan-bahan atau materi pelajaran yang akan diajarkan. Buku ajar disusun secara sistematis dan dapat mengacu pada suatu model pembelajaran tertentu yang sesuai dengan kurikulum, tingkat perkembangan peserta didik, dan lingkungan sekitar.

Bahan ajar dapat mempengaruhi kualitas pembelajaran termasuk kualitas hasil belajar. Oleh karena itu, bahan ajar memiliki fungsi dalam pembelajaran dan memegang peranan yang sangat penting dan turut menentukan tercapainya tujuan pendidikan. Joni (1984) dalam Harijanto (2007), mengungkapkan beberapa fungsi bahan ajar yaitu: (1) memberikan petujuk yang jelas bagi pembelajar dalam mengelola kegiatan pembelajaran; (2) menyediakan bahan atau alat yang lengkap yang diperlukan untuk setiap kegiatan; (3) merupakan media penghubung antara pembelajar dengan pebelajar; dan (4) dapat dipakai oleh pebelajar sendiri untuk mencapai kemampuan yang telah ditetapkan.

Bahan ajar sangat penting artinya bagi guru dan siswa dalam proses pembelajaran. Bagi guru, bahan ajar dapat berperan dalam menghemat waktu, mengubah peran guru sebagai fasilitator, membantu proses pembelajaran sehingga tercipta proses pembelajaran yang Aktif, Kreatif, Inovatif, Efektif, dan Menyenangkan (PAIKEM). Bagi siswa, bahan ajar dapat berperan membantu siswa dalam memahami materi pelajaran dan membantu mereka dalam mengembangkan potensi untuk belajar madiri.

Agar bahan ajar yang dipilih dapat berfungsi sebagaimana mestinya, maka dalam pengembangannya, bahan ajar harus memenuhi komponen-kompenen yang relevan dengan kurikulum, kebutuhan pebelajar, dan karakteristik mata pelajaran. Komponen-komponen tersebut juga harus dapat memberikan motivasi, mudah dipelajari dan dipahami pebelajar.

Bahan ajar merupakan perpaduan beberapa komponen yang disusun secara sistematis. Komponen-komponen ini disebut sebagai struktur bahan ajar. Secara umum terdapat tujuh komponen dalam setiap bahan ajar, yaitu: (1) judul; (2) petunjuk belajar; (3) kompetensi dasar atau materi pokok; (4) informasi pendukung; (5) latihan; (6) tugas atau langkah kerja; dan (7) penilaian (Prastowo, 2011).

Sebuah buku yang digunakan sebagai bahan ajar harus diturunkan dari kompetensi dasar yang tertuang dalam kurikulum, sehingga buku akan memberi makna sebagai bahan ajar bagi peserta didik yang mempelajarinya (Depdiknas 2007). Toto (2012), menyatakan bahwa berdasarkan substansinya, buku sebagai bahan ajar harus memenuhi beberapa prinsip yaitu kelayakan isi, keterbacaan, dan grafika. Sementara dalam Pedoman 
Pengembangan Bahan Ajar Depdiknas (2008), menyebutkan komponen evaluasi bahan ajar mencakup: (1) kelayakan isi mencakup: kesesuaian dengan kurikulum, kesesuaian dengan kondisi, materi yang spesifik, jelas dan akurat sesuai dengan kebutuhan bahan ajar, kesesuaian dengan nilai moral dan nilai social, bermanfaat untuk menambah wawasan siswa, keseimbangan dalam penjabaran materi (pengembangan makna dan pemahaman, pemecahan masalah, pengembangan proses, latihan dan praktik, tes keterampilan maupun pemahaman; (2) kebahasaan mencakup: keterbacaan, kejelasan informasi, kesesuaian dengan kaidah bahasa Indonesia yang baik dan benar, dan pemanfaatan bahasa secara efektif dan efisien; (3) sajian mencakup: kejelasan tujuan pembelajaran, urutan sajian (keteraturan urutan dalam penguraian sajian), memotivasi dan menarik perhatian siswa, interaksi (pemberian stimulus dan respon) untuk mengaktifkan siswa, kelengkapan informasi (bahan, latian dan soal); dan (4) kegrafikaan mencakup: penggunaan font, bentuk tulisan, ukuran huruf, dan jarak spasi, tata letak (lay out), ilustrasi, gambar, dan foto, dan desain tampilan.

Menurut Brog dan Gall (1983) dalam Ghufron (2005), terdapat sepuluh langkah penelitian dan pengembangan yaitu (1) penelitian dan pengumpulan data; (2) perencanaan; (3) pengembangan produk awal; (4) ujicoba awal; (5) revisi produk; (6) ujicoba akhir; (7) revisi produk operasional; (8) uji kelayakan; (9) pengujian produk akhir; dan (10) desiminasi dan implementasi. Belawati (2006) dalam Toto (2012), menyebutkan 5 langkah pengembangan bahan ajar yaitu: (1) analisis; (2) perancangan; (3) pengembangan; (4) evaluasi; dan (5) revisi. Pada tahap analisis, pengembang harus mengenali karakteristik dan prilaku pebelajar, tuntutan silabus, dan kebutuhan siswa dan guru.

Pada tahap perancangan, dilakukan perumusan tujuan pembelajaran. Perumusan tujuan pembelajaran ini, didasarakan pada analisis, pemilihan konsep-konsep dan topik, pemilihan media dan sumber, dan pemilihan model pembelajaran.

Pada tahap pengembangan, pengembang menyusun bahan ajar secara utuh, dilanjutkan pada tahap berikutnya yaitu evaluasi yang merupakan tahap yang harus dilalui untuk memperoleh masukan bagi penyempurnaan bahan ajar yang telah dikembangkan.

Bertitik tolak pada paparan di atas maka sangat diperlukan upaya mengembangkan bahan ajar yang berkualitas yang sesuai dengan kebutuhan, memudahkan siswa serta memberikan peluang kepada siswa untuk dapat bereksplorasi, menumbuhan sikap ilmiah, pemerolehan konsep sendiri (inquiry), dan menerapkan konsep tersebut dalam penyelesaian permasalahan. Dengan dukungan bahan ajar dan proses pembelajaran yang 
berkualitas, diharapkan dapat meningkatkan aktivitas belajar sehingga berdampak pada peningkatan hasil belajar fisika siswa.

Rumusan masalah dalam penelitian ini adalah bagaimanakah pengembangan bahan ajar fisika SMA berbasis Learning Cycle 3E? Bagaimana karakteristik bahan ajar fisika berbasis learning cycle 3E? Bagaimana kelayakan bahan ajar fisika berbasis Learning Cycle 3E? Apakah bahan ajar yang dikembangkan efektif untuk meningkatkan hasil belajar fisika siswa?. Untuk menjawab permasalahan di atas, penelitian pengembangan yang menghasilkan produk bahan ajar fisika berbasis learning cycle $3 E$, mengetahui keefektifannya dalam meningkatkan hasil belajar fisika siswa, dan mengetahui kelayakannya dalam pembelajaran fisika di SMA.

\section{Metode Penelitian}

Penelitian ini dirancang berdasarkan langkah-langkah dalam metode penelitian dan Pengembangan (Research and Development/R\&D) yang di adaptasi dari Borg and Gall (1983), dengan langkah-langkah:

1. Tahap Studi Pendahuluan

Tahap ini dilakukan untuk memperoleh data awal tentang permasalahan pada proses penyelenggaraan pembelajaran fisika tingkat SMA di kota Mataram, tanggapan dari calon pengguna dan kajian terhadap bahan ajar yang meliputi: (a) studi literatur untuk menemukan konsep atau landasan teoritis yang memperkuat produk bahan ajar, langkah-langkah yang tepat untuk mengembangkan produk bahan ajar, dan memberikan gambaran hasil penelitian terdahulu sebagai bahan perbandingan untuk mengembangkan produk bahan ajar; (b) studi lapangan untuk mengidentifikasi bahan ajar fisika yang selama ini di gunakan guru dan siswa, melakukan observasi dan wawancara untuk melihat kesesuaian bahan ajar yang digunakan dengan karakteristik mata pelajaran dan model pembelajarannya; (c) deskripsi temuan dan analisis kebutuhan bahan ajar menurut guru dan siswa.

2. Tahap Studi Pengembangan

Tahap ini merupakan tidak lanjut dari analisis temuan bahan ajar yang telah dilakukan pada tahap pendahuluan. Pada tahap ini dikembangkan desain produk awal (prototype) bahan ajar fisika berbasis learning cycle dan perangkat pembelajaran sebagai pendukung bahan ajar tersebut. 
Langkah selanjutnya adalah validasi ahli/pakar tehadap produk awal dan perangkat pembelajaran yang telah disusun. Validasi ini dilakuakan oleh 3 orang pakar untuk mendapatkan koreksi dan masukan yang berkaitan dengan kelayakan isi, kebahasaan, penyajian, dan grafika terhadap desain produk awal dan perangkat yang telah disusun. Dari koreksi dan masukan ini kemudian dilakukan evaluasi dan perbaikan sehingga diperoleh desain produk awal yang lebih layak. Selanjutnya dilakukan uji coba terbatas dengan melibatkan 10 orang siswa dan 1 orang guru. Hasil uji coba terbatas ini digunakan untuk evaluasi dan revisi untuk mendapatkan produk yang sempurna.

3. Tahap Pengujian Bahan Ajar

Tahap pengujian bahan ajar dimaksudkan untuk melihat keunggulan bahan ajar yang telah dikembangkan dengan bahan ajar lama yang di gunakan guru dan siswa. Tahap ini dilakukan melalui metode penelitian ekperimen, yaitu pretest-posttes control group design dengan rancangan penelitian sebagai berikut:

Tabel 1: Desain ekperimen penerapan produk bahan ajar fisika berbasis learning cycle.

\begin{tabular}{|c|c|c|c|}
\hline $\begin{array}{c}\text { Kelompok } \\
\text { Kelas }\end{array}$ & Pretest & $\begin{array}{c}\text { Treatment } \\
\text { (Produk bahan ajar) }\end{array}$ & Posttest \\
\hline Ekperimen & Ya & Ya & Ya \\
\hline Kontrol & Ya & Tidak & Ya \\
\hline
\end{tabular}

Populasi dalam penelitian ini adalah seluruh siswa kelas XI IPA SMA Negeri 5 Mataram tahun ajaran 2012/2013. Teknik pengambilan sampel yang digunakan adalah teknik Simple random Sampling sehingga diperoleh kelas XI IPA 2 sebagai kelas eksperimen dan kelas XI IPA 5 sebagai kelas kontrol.

Instrumen utuk mengumpulkan data adalah: (1) lembar observasi tahap pendahulauan; (2) lembar validasi ahli; (3) lembar observasi keterlaksaan pembelajaran; (4) angket respon guru dan siswa terhadap bahan ajar yang dikembangkan; (5) tes hasil belajar untuk memperoleh informasi tentang efektivitas bahan yang dikembangkan dalam meningkatkan hasil belajar fisika siswa.

Observasi dilakukan untuk memperoleh data kebutuhan bahan ajar menurut guru dan siswa. Dari data ini kemudian dianalisis sebagai pedoman dalam mengembangkan prototype bahan ajar baru. Lembar observasi juga dimaksudkan untuk memperoleh data keterlaksaanaan pembelajaran dengan menggunakan model pembelajaran learning cycle $3 E$. 
Lembar validasi digunakan untuk mendapatkan data kekurangan prototype bahan ajar baru dan untuk menguji kelayakan produk akhir bahan ajar baru. Untuk menguji kelayakan bahan ajar baru menggunakan komponen evaluasi yang mencakup (1) kelayakan isi; (2) kebahasaan; (3) penyajian materi; dan (4) grafika. Instrumen ini menggunakan pilihan alternatif jawaban: sangat baik (SB), baik (B), cukup baik (CB), tidak baik (TB), sangat tidak baik (STB). Instrumen tersebut disusun berdasarkan pedoman pengembangan bahan ajar (Depdiknas, 2008). Peneliti memaparkan proses desain produk bahan ajar kemudian dilakukan diskusi dengan para pakar sebagai validator yang sudah berpengalaman untuk menilai produk bahan ajar. Selanjutnya masukan dan saran validator dijadikan acuan untuk kesempurnaan produk bahan ajar.

Tes hasil belajar dilakukan sebelum penerapan bahan ajar baru (pretest) dan setelah pembelajaran dengan menggunakan bahan ajar baru (posttes). Tes yang sama juga diberikan di kelas kontrol untuk melihat perbandingan bahan ajar lama dan baru. Instrumen tes ini digunakan untuk mendapatkan data keefektifan bahan ajar baru untuk meningkatkan penguasaan konsep fisika siswa. Instrumen ini terdiri dari soal penguasaan konsep fisika berupa pilihan ganda sebanyak 28 butir soal yang telah di uji reliabilitas, validitas, indeks kesukaran dan daya pembedanya.

Untuk mengetahui peningkatan hasil belajar fisika siswa yang menggunakan bahan ajar fisika berbasis learning cycle $3 E$, maka skor pretest dan skor posttest dari kelas ekperimen dan kelas kontrol dianalisis dengan menggunakan rumus $\mathrm{N}$-gain (Hake, 1999 dalam Maharika, 2011), yaitu: $N-$ gain $=\frac{S_{\text {post }}-S_{\text {pre }}}{S_{\text {maks }}-S_{\text {pre }}}$ Dimana: $N$-gain = Gain yang dinormalisasi, Spre $=$ Skor pretest, Spost $=$ Skor posttest, Smaks $=$ skor maksimal ideal. Hake (1999), dalam Mahardika (2011), memberikan kategori perolehan nilai $\mathrm{N}$-gain sebagai berikut: tinggi: $N$-gain $\geq 0,7$, sedang: $0,3<N$-gain $<$ 0,7, dan rendah: $N$-gain $\leq 0,3$.

Uji hipotesis dimaksudkan untuk membuktikan efektifitas bahan ajar fisika berbasis Learning Cycle dalam meningkatkan hasil belajar fisika siswa kelas XI IPA di SMA Negeri 5 Mataram. Uji hipotesis ini menggunakan analisis kovarians (Anakova). Analisis ini dipilih dengan maksud untuk melihat kemurnian pengaruh variabel bebas (pembelajaran dengan bahan ajar learning cycle) terhadap variabel terikat (penguasaan konsep fisika siswa) dari variabel konkomitan (Sudjana, 2002).

Langkah-langkah pengujian hipotesis ini dapat dilihat pada tabel berikut: 
Tabel 2: Daftar analisis anakova untuk faktor tunggal dengan sebuah kovariabel

\begin{tabular}{|c|c|c|c|c|c|c|c|c|}
\hline \multirow[t]{2}{*}{ Sumber Variasi } & \multirow[t]{2}{*}{$\mathrm{dk}$} & \multicolumn{3}{|c|}{$\begin{array}{c}\text { Jumlah Kuadrat-Kuadrat } \\
\text { dan Produk Silang }\end{array}$} & \multicolumn{3}{|c|}{$\begin{array}{c}\text { Disesuikan (Dikoreksi) } \\
\text { karena Regresi }\end{array}$} & \multirow[t]{2}{*}{$\mathrm{F}$} \\
\hline & & $\mathrm{X}$ & $X Y$ & $\mathrm{Y}$ & $Y$ & Dk & KT & \\
\hline $\begin{array}{l}\text { Perlakuan } \\
\text { Galat }\end{array}$ & $\begin{array}{l}a-1 \\
\mathrm{~N}-a\end{array}$ & & $\begin{array}{l}P_{x y} \\
E_{x y}\end{array}$ & $\begin{array}{c}\mathrm{P}_{\mathrm{yy}} \\
\mathrm{E}_{\mathrm{yy}}\end{array}$ & $\mathrm{J}_{\mathrm{E}}$ & $\mathrm{N}-a-1$ & $E=\frac{J_{E}}{N-a-1}$ & \multirow{3}{*}{$\frac{P}{E}$} \\
\hline Total & $\mathrm{N}-1$ & & & & $\mathrm{~J}_{\mathrm{E}}^{\prime}$ & $\mathrm{N}-2$ & & \\
\hline $\begin{array}{l}\text { Perlakuan } \\
\text { disesuaikan }\end{array}$ & & & & & $\mathrm{J}_{\mathrm{E}}^{\prime}-\mathrm{J}_{\mathrm{E}}$ & $a-1$ & $P=\frac{J_{E}^{\prime}-J_{E}}{a-1}$ & \\
\hline
\end{tabular}

Hipotesis statistik yang akan diuji adalah:

$H_{o}: \mu_{i}=\mu_{a}$ : Tidak terdapat perbedaan antara hasil belajar fisika kelas kontrol $\left(\mu_{\mathrm{i}}\right)$ dengan penguasaan konsep fisika kelas eksperimen $\left(\mu_{\mathrm{a}}\right)$

$H_{a}: \mu_{i}<\mu_{a}: \quad$ Terdapat perbedaan antara antara hasil belajar fisika kelas kontrol $\left(\mu_{\mathrm{i}}\right)$ dengan penguasaan konsep fisika kelas eksperimen $\left(\mu_{\mathrm{a}}\right)$

Kriteria uji statistik adalah jika diperoleh nilai $F_{\text {hitung }} \leq F_{\text {tabel }}$ maka $\mathrm{H}_{0}$ diterima dan $\mathrm{H}_{\mathrm{a}}$ ditolak, sedangkan jika diperoleh nilai $F_{\text {tabel }}<F_{\text {hitung }}$ maka $\mathrm{H}_{0}$ ditolak dan $\mathrm{H}_{\mathrm{a}}$ diterima pada taraf signifikansi $5 \%$.

\section{Hasil dan Pembahasan}

1. Hasil Studi Pendahuluan

Tahap studi pendahuluan diawali dengan studi literatur. Langkah ini dimaksudkan untuk menemukan landasan teoritis yang memperkuat produk bahan ajar yang dikembangkan, menentukan langkah-langkah pengembangan yang benar, dan mendeskripsikan hasil penelitian terdahulu yang dijadikan bahan perbandingan dalam pengembangan produk bahan ajar.

Tahap observasi telah dilakukan dalam bentuk penyebaran angket dan wawancara terhadap guru-guru fisika di tiga SMA Negeri di Kota Mataram, masingmasing SMAN 5 Mataram yang mewakili kelompok sekolah kategori I, SMAN 2 Mataram yang mewakili kelompok sekolah kategori II dan SMAN 6 Mataram yang mewakili kelompok sekolah kategori III (Purwoko, 2009). Observasi ini bertujuan untuk mengetahui proses penyelenggaraan pembelajaran fisika di tiga SMA tersebut. Hasil observasi menunjukkan kesamaan data, yaitu: (1) pemanfaatan model-model pembelajaran yang sesuai dengan karakteristik fisika (misalnya learning cycle) sebagai panduan dalam perencanaan dan pelaksanaan pembelajaran fisika belum 
maksimal. Walaupun pada tahap penyusunan rencana (RPP) guru menggunakan model pembelajaran tertentu sebagai panduan, tetapi pada tahap pelaksanaan RPP tersebut tidak dimanfaatkan dengan baik. RPP hanya dijadikan kelengkapan administrasi untuk disimpan dan dikeluarkan jika ada monitoring dari Kepala Sekolah atau Pengawas pendidikan. Hal ini berdampak pada proses pembelajaran yang tidak efisien baik dari segi pencapain tujuan maupun dari segi waktu; (2) Penggunaan buku sebagai sumber belajar masih didominasi dengan penggunaan buku teks atau LKS dari penerbit tertentu. Buku teks atau LKS yang digunakan tidak terlepas dari kelemahankelemahan diantaranya: bahasa yang digunakan terkadang membingungkan siswa, uraian materi pada LKS tidak merepresentasikan indikator-indikator dalam silabus sehingga menyulitkan siswa dalam melakukan tahap eksplorasi dan pengenalan konsep, penerapan konsep siswa lebih menekankan pada penyelesaian soal-soal yang bersifat kuantiatif; (3) Pengembangan dan inovasi bahan ajar fisika untuk menanggulangi kelemahan bahan ajar yang dipakai selama ini belum dilakukan oleh guru dengan alasan kesulitan dan belum ada contoh yang bisa dijadikan sebagai panduan; (4) semua guru fisika yang diobservasi setuju dengan dilakukan pengembangan bahan ajar berbasis learning cycle $3 E$.

\section{Pengembangan Bahan ajar}

Deskripsi temuan dan analisis kebutuhan bahan ajar pada tahap studi pendahuluan dijadikan dasar untuk tahap pengembangan. Tahap ini meliputi desain produk awal (prototype) dan penyusunan perangkat pembelajaran sebagai pendukung, validasi oleh pakar, evaluasi dan perbaikan, uji coba terbatas, dan evaluasi untuk penyempurnaan sehingga diperoleh draf akhir bahan ajar yang lebih sempurna yang selanjutnya siap untuk di uji efektivitas dan kelayakannya.

a. Desain Produk Awal (Prototype) dan Penyusunan Perangkat Pembelajaran.

Penyusunan prototype bahan ajar fisika berbasis learning cycle $3 E$ merupakan proses penyusunan dan pengorganisasian materi pembelajaran fisika berdasarkan sintaks model pembelajaran learning cycle 3E. Prototype bahan ajar adalah bagian dari perencanaan sebuah bahan ajar yang dimungkinkan untuk dilakukan revisi berdasarkan validasi dan uji coba. Penyusunan prototype ini dilakukan dengan tiga tahap yaitu: Analisis kurikulum, analisis materi 
pembelajaran, dan pengorganisasian materi pembelajaran berdasarkan model pembelajaran learning cycle $3 E$.

Analsis kurikulum dilakukan dengan tujuan supaya prototype bahan ajar yang disusun sesuai dengan kurikulum yang berlaku. Pada tahap ini ditentukan kompetensi dasar, materi pokok, indikator, dan tujuan yang diharapkan. Hasil analisis Kurikulum dituangkan dalam matrik analisis kurikulum mata pelajaran fisika kelas XI IPA pada Komptensi Dasar 3 yaitu menerapkan konsep termodinamika dalam mesin kalor.

Tabel 3: Hasil Analisis Kurikulum

\begin{tabular}{|c|c|c|c|}
\hline Komptensi dasar & $\begin{array}{l}\text { Materi } \\
\text { pokok }\end{array}$ & Indikator & Tujuan \\
\hline \multirow[t]{2}{*}{$\begin{array}{l}\text { 3.1Mendeskripsika } \\
\mathrm{n} \text { sifat-sifat gas } \\
\text { ideal } \\
\text { monoatomik }\end{array}$} & \begin{tabular}{|l} 
Teori \\
kinetik gas \\
- Persamaan \\
umum gas
\end{tabular} & $\begin{array}{l}\text { Menerapkan } \\
\text { persamaan umum gas } \\
\text { ideal pada proses } \\
\text { isotermik, isokhorik, } \\
\text { dan isobarik } \\
\text { Mendeskripsikan } \\
\text { persamaan umum gas } \\
\text { ideal pada persoalan } \\
\text { fisika sehari-hari }\end{array}$ & $\begin{array}{l}\text { 1. Menjelaskan hubungan antara } \\
\text { tekanan, suhu, dan volume gas } \\
\text { 2. Menerapkan persamaan gas ideal } \\
\text { pada proses isotermik, isokhorik, } \\
\text { dan isobaric } \\
\text { 3. Menjelaskan besaran-besaran } \\
\text { mikroskopis yang berkaitan } \\
\text { dengan gas } \\
\text { 4. Menerapkan persamaan umum } \\
\text { gas ideal pada persoalan fisika } \\
\text { sehari-hari }\end{array}$ \\
\hline & $\begin{array}{l}\text { Tekanan } \\
\text { dan energi } \\
\text { kinetik gas }\end{array}$ & $\begin{array}{l}\text { Mengidentifikasi } \\
\text { hubungan tekanan, } \\
\text { suhu, dan energi } \\
\text { kinetik gas }\end{array}$ & $\begin{array}{l}\text { 1. Menjelaskan hubungan antara } \\
\text { tekanan, suhu, dan energi kinetik } \\
\text { gas ideal. } \\
\text { 2. Menerapkan persamaan tekanan, } \\
\text { suhu, dan energi kinetik gas ideal. } \\
\text { 3. Menjelaskan tentang kelajuan } \\
\text { efektif gas serta mampu } \\
\text { menggunakannnya dalam } \\
\text { menyelesaikan masalah. }\end{array}$ \\
\hline $\begin{array}{l}\text { 3.2Menganalisis } \\
\text { perubahan } \\
\text { keadaan gas } \\
\text { ideal dengan } \\
\text { menerapkan } \\
\text { hukum } \\
\text { termodinamika }\end{array}$ & $\begin{array}{l}\text { Termodina } \\
\text { mika } \\
\text { - Hukum } \\
\text { utama } \\
\text { termodina } \\
\text { mika } \\
\text { Mesin } \\
\text { Carnot }\end{array}$ & $\begin{array}{l}\text { Menganalisis proses } \\
\text { gas ideal berdasarkan } \\
\text { grafik tekanan-volume } \\
(\mathrm{P}-\mathrm{V})\end{array}$ & $\begin{array}{l}\text { 1. Menjelaskan tentang konsep } \\
\text { usaha, dan energi dalam pada } \\
\text { proses termodinamika. } \\
\text { 2. Menjelaskan beberapa proses } \\
\text { termodinamika, seperti isotermik, } \\
\text { isokhorik, isobarik, dan adiabatik. } \\
\text { 3. Menerapkan konsep usaha pada } \\
\text { proses isotermik, isokhorik, dan } \\
\text { isobarik. } \\
\text { 4. Menganalisis proses gas ideal } \\
\text { berdasarkan grafik tekanan- } \\
\text { volume (P-V) }\end{array}$ \\
\hline
\end{tabular}




\begin{tabular}{|c|c|c|c|}
\hline & & $\begin{array}{l}\text { Mendeskripsikan } \\
\text { usaha, kalor, dan } \\
\text { energi dalam } \\
\text { berdasarkan hukum } \\
\text { utama termodinamika }\end{array}$ & $\begin{array}{l}\text { 1. } \text { Menjelaskan tentang konsep } \\
\text { hukum pertama termodinamika. } \\
\text { 2. Menjelaskan aplikasi hukum } \\
\text { pertama termodinamika pada } \\
\text { keadaan isotermik, isokhorik, } \\
\text { isobarik, dan adiabatik. } \\
\text { 3. Menerapkan konsep hukum } \\
\text { pertama termodinamika untuk } \\
\text { memecahkan permasalahan. }\end{array}$ \\
\hline & & $\begin{array}{l}\text { - Mendeskripsikan } \\
\text { prinsip kerja mesin } \\
\text { Carnot }\end{array}$ & $\begin{array}{l}\text { 1. } \begin{array}{l}\text { Menjelaskan tentang konsep } \\
\text { mesin kalor dan mesin carnot. }\end{array} \\
\text { 2. Menjelaskan tentang konsep } \\
\text { usaha, proses termodinamik dan } \\
\text { efisiensi pada mesin carnot. } \\
\text { 3. } \begin{array}{l}\text { Menerapkan konsep mesin carnot } \\
\text { untuk memecahkan } \\
\text { permasalahan. }\end{array}\end{array}$ \\
\hline
\end{tabular}

Tahap analisis materi pelajaran fisika bertujuan untuk mengidentifikasi dan menyusun konsep, prinsip, hukum, dan teori yang sesuai dengan standar kompetensi, kompetensi dasar, dan indikator hasil analisis kurikulum dari berbagai sumber. Pada tahap ini juga dilakukan pengumpulan informasi pendukung terhadap materi pokok pada bahan ajar yang akan digunakan pada tahap eksplorasi seperti gambar-gambar, mini lab., dan bahan-bahan diskusi. Selain itu dikumpulkan juga informasi pendukung pada tahap aplikasi konsep seperti penomena-penomena yang terjadi dalam kehidupan sehari-hari yang bersesuain dengan materi, penggunaan konsep-konsep pada produk teknologi, dan soal-soal untuk contoh dan latihan mandiri.

Tahap Pengorganisasian materi pembelajaran berdasarkan model pembelajaran learning cycle dilakukan penyusunan prototype bahan ajar yang disesuikan dengan langkah-langkah model pembelajaran learning cycle. Langkah pertama yang dilakukan pada tahap ini adalah penentuan judul, subjudul, tujuan pembelajaran yang akan dicapai, pengorganisasian materi pada tahap eksplorasi, pengorganisasian materi pada tahap pengenalan konsep, pengorganisasian materi pada tahap aplikasi konsep, dan penentuan soal-soal hasil belajar sebagai latihan mandiri siswa. Selain prototype bahan ajar, disusun pula perangkat pendukungnya seperti RPP.

b. Validasi Ahli

Tahap validasi ahli merupakan salah satu tahap dalam penelitian pengembangan. Hasil validasi ahli dapat dilihat pada tabel berikut: 
Tabel 4: Hasil validasi Ahli terhadap prototype bahan ajar dan perangkat pendukungnya.

\begin{tabular}{|c|c|c|c|c|c|c|c|}
\hline \multirow{2}{*}{ No } & \multirow{2}{*}{ Aspek yang dinilai } & \multicolumn{4}{|c|}{ Skor } & \multirow{2}{*}{$\begin{array}{l}\text { Prosentase } \\
(\%)\end{array}$} & \multirow{2}{*}{ Kriteria } \\
\hline & & A.1 & A. 2 & A.3 & Rata-rata & & \\
\hline \multirow[t]{6}{*}{1} & \multicolumn{7}{|c|}{ Kualitas Prototype bahan ajar } \\
\hline & a. $\quad$ Kelayakan isi & 4,14 & 3,86 & 4,14 & 4,05 & 81,0 & Baik \\
\hline & b. Kebahasaan & 4,00 & 3,83 & 4,00 & 3,94 & 78,8 & Baik \\
\hline & c. Penyajian & 4,00 & 3,80 & 4,00 & 3,93 & 78,6 & Baik \\
\hline & d. Kegrafisan & 3,83 & 3,80 & 3,67 & 3,77 & 75,4 & Baik \\
\hline & Total rata-rata & & & & 3,92 & 78,4 & Baik \\
\hline 2 & \multicolumn{7}{|c|}{ Kualitas Perangkat-perangkat pendukung } \\
\hline & RPP & 4,07 & 3,90 & 4,02 & 4,00 & 80,0 & Baik \\
\hline & $\begin{array}{l}\text { Instrumen soal hasil belajar } \\
\text { fisika }\end{array}$ & 4,00 & 3,90 & 3,80 & 3,90 & 78,0 & Baik \\
\hline & \multicolumn{4}{|l|}{ Total rata-rata } & 3,95 & 79,0 & Baik \\
\hline \multicolumn{8}{|c|}{$\begin{array}{l}\text { Keterangan: } \\
\text { Skor berada pada interval } 1 \\
4,20-5,00=\text { Baik sekali } \\
3,40-4,19=\text { Baik } \\
2,60-3,39=\text { Kurang baik } \\
1,80-2,59=\text { Jelek } \\
1,00-1,79=\text { Jelek sekali }\end{array}$} \\
\hline
\end{tabular}

Dari tabel di atas dapat diperoleh gambaran bahwa hasil validasi ahli menunjukkan bahwa prototype bahan ajar fisika berbasis learning cycle mendapatkan penilaian dengan kriteria baik, sehingga rancangan bahan ajar ini layak untuk dilanjutkan pada tahap uji coba terbatas. Demikian juga dengan perangkat pendukungnya seperti RPP dan instrumen soal hasil belajar fisika siswa mendapatkan penilaian dengan kriteria baik, sehingga layak untuk digunakan sebagai pedoman pelaksanaan pembelajaran dan alat pengambilan data hasil belajar fisika siswa.

c. Evaluasi dan Perbaikan

Pada bagian akhir lembar validasi juga disediakan ruang catatan bagi pada validator untuk menilai aspek-aspek yang belum tercantum dalam lembar validasi. Beberapa masukan dari para ahli diantaranya (1) Ukuran, warna, dan tata letak gambar-gambar pendukung pada bahan ajar hendaknya tidak monoton; (2) Sumber-sumber pengambilan gambar pendukung hendaknya dituliskan; (3) hendaknya pemberian kunci jawaban pada soal-soal latihan mandiri tidak dipilihpilih, melainkan semua soal diberikan kunci jawabannya; (4) hendaknya konsisten dalam cara penulisan dengan cetak tebal dan penulisan dengan cetak miring pada hal-hal yang memiliki kesamaan tujuan; (5) setiap rumus hendaknya diberikan nomor; (6) hendaknya penulisan tujuan pada bahan ajar dan RPP memperhatikan kaidah Audience, Behavior, Conditions, and Degree (ABCD); dan (7) hendaknya 
pada soal-soal hasil belajar ditambahkan dengan soal-soal fisika yang sifatnya kualitatif.

Dari masukan para ahli di atas selanjutnya dilakukan perbaikan-perbaikan sehingga diperoleh prototype bahan ajar yang lebih baik dan siap untuk dilakukan uji coba pada sekala terbatas.

d. Uji coba Terbatas

Prototype bahan ajar yang telah divalidasi oleh para ahli selanjutnya diuji coba pada skala terbatas. Uji coba skala terbatas ini melibatkan 32 orang siswa kelas X IPA yang mengambil beban belajar semester atas (program SKS) dan 1 orang guru fisika kelas XI. Uji coba ini dimaksudkan untuk memperoleh informasi dari siswa dan guru sebagai pengguna bahan ajar dan guru fisika kelas XI berkaitan dengan cakupan materi atau kelayakan isi, kebahasaan, penyajian, dan kegrafisannya.

Hasil pengisian angket untuk mendapatkan tanggapan terhadap rancangan bahan ajar pada saat uji coba terbatas ditampilkan pada tabel berikut:

Tabel 5: Hasil tanggapan siswa dan guru terhadap prototype bahan ajar fisika berbasis learning cycle

\begin{tabular}{|c|c|c|c|c|c|c|}
\hline \multirow[b]{2}{*}{ No } & \multirow[b]{2}{*}{ Aspek yang dinilai } & \multicolumn{3}{|c|}{ Pengguna } & \multirow[b]{2}{*}{$\begin{array}{c}\text { Prosentase } \\
(\%)\end{array}$} & \multirow[b]{2}{*}{ Kriteria } \\
\hline & & siswa & Guru & Rata-rata & & \\
\hline 1 & Kelayakan isi & 4,23 & 4,29 & 4,26 & 85,2 & Baik sekali \\
\hline 2 & Kebahasaan & 4,13 & 4,17 & 4,15 & 83,0 & Baik \\
\hline 3 & Penyajian & 4,11 & 4,20 & 4,16 & 83,2 & Baik \\
\hline 4 & Kegrafisan & 4,29 & 4,75 & 4,52 & 90,4 & Baik sekali \\
\hline \multicolumn{2}{|c|}{ Rata-rata } & & 4,27 & & 84,5 & Baik sekali \\
\hline \multicolumn{7}{|c|}{$\begin{array}{l}\text { Keterangan: } \\
\text { Skor berada pada interval } 1-5 \\
4,20-5,00=\text { Baik sekali } \\
3,40-4,19=\text { Baik } \\
2,60-3,39=\text { Kurang baik } \\
1,80-2,59=\text { Jelek } \\
1,00-1,79=\text { Jelek sekali }\end{array}$} \\
\hline
\end{tabular}

Tabel di atas memberikan gambaran bahwa rancangan bahan ajar ini mendapat tanggapan sangat baik, tetapi belum dikatakan sempurna karena masih ada beberapa masukan dari siswa dan guru selaku pengguna bahan ajar tersebut.

e. Evaluasi dan Penyempurnaan

Pada akhir tahap uji coba terbatas siswa dan guru fisika kelas XI diberikan ruang untuk memberikan masukan terhadap bahan ajar yang digunakan. Beberapa masukan yang diperoleh diantaranya adalah (1) sebaiknya materi pokok entropi 
tidak dimuat karena tidak sesuai dengan SK dan KD pada silabus; (2) sebaiknya bahan ajar yang dikembangkan di berikan kata pengantar yang isinya mencantumkan kelebihan bahan ajar tersebut; (3) hendaknya bahan ajar yang dikembangkan diberi daftar isi sehingga memudahkan penggunaan bahan ajar bagi para pengguna; (4) Desain grafis pada sampul bahan ajar hendaknya lebih menarik; dan (5) dalam bahan ajar masih terdapat kesalahan dalam pengetikan sehingga perlu di baca berulang-ulang untuk perbaikan

Berdasarkan masukan yang diperoleh pada uji coba skala terbatas ini selanjutnya dilakukan perbaikan dan penyempurnaan. Apek-aspek yang diperbaiki dan disempurnakan adalah seperti yang tertera pada tabel 6 dibawah ini:

Tabel 6: Aspek-aspek bahan ajar yang disempurnakan berdasarkan hasil uji coba terbatas.

\begin{tabular}{|l|l|}
\hline \multicolumn{1}{|c|}{$\begin{array}{c}\text { Aspek yang } \\
\text { Dievaluasi }\end{array}$} & \multicolumn{1}{c|}{ Substansi Penyempurnaan } \\
\hline $\begin{array}{l}\text { Materi bahan } \\
\text { ajar }\end{array}$ & $\begin{array}{l}\text { Penghapusan materi pokok yang membahas entropi pada bagian akhir bahan } \\
\text { ajar, karena memang tidak tercantum di dalam silabus }\end{array}$ \\
\hline Kebahasaan & $\begin{array}{l}\text { Pada beberapa kata bahkan kalimat dalam bahan ajar diperiksa dengan teliti } \\
\text { untuk ditemukan salah pengetikan dan kesalahan dalam susunan kalimat } \\
\text { kemudian dibetulkan sehingga bahan ajar memiliki kejelasan informasi }\end{array}$ \\
\hline Penyajian & $\begin{array}{l}\text { 1. Dilakukan penambahan kata pengantar untuk memberikan gambaran } \\
\text { pengguna tentang kelebihan gahan ajar dan sekaligus sebagai petunjuk } \\
\text { belajar. }\end{array}$ \\
2. Dilakukan penambahan daftar isi pada bagian awal bahan ajar sehingga \\
bahan ajar memiliki kelengkapan informasi
\end{tabular}

\section{Hasil Pengujian bahan ajar}

Rancangan Bahan ajar yang lebih sempurna diperoleh setelah dilakukan perbaikan pada aspek-aspek yang mendapat tanggapan pada tahap uji coba terbatas. Tahap selanjutnya adalah uji coba lebih luas sekaligus sebagai tahap pengujian melalui implementasi rancangan bahan ajar. Tahap ini melibatkan 65 siswa yang terdiri dari 2 kelas dengan metode eksperimen. Kelas XI IPA 1 sebagai kelas ekperimen menggunakan bahan ajar fisika berbasis learning cycle dan kelas XI IPA 5 sebagai kelas kontrol menggunakan bahan ajar lama. Tahap ini bertujuan untuk mengetahui efektif atau tidaknya rancangan bahan ajar ini dalam meningkatkan hasil belajar fisika siswa melalui proses pembelajaran di kelas.

Sebelum dilakukan implementasi bahan ajar, kedua kelas diberikan soal pretest dengan soal hasil belajar fisika yang terdiri dari 28 soal dan setelah 
implementasi bahan ajar kedua kelas diberikan posttest dengan soal yang sama. Skor pretest dan skor posttest masing-masing kelas ditampilkan pada tabel berikut.

Tabel 7: Perolehan skor pada kelas kontrol dan kelas ekperimen terhadap soal hasil belajar fisika

\begin{tabular}{|l|c|c|c|c|}
\hline \multirow{2}{*}{ Perolehan } & \multicolumn{2}{|c|}{ Kelas kontrol } & \multicolumn{2}{c|}{ Kelas ekperimen } \\
\cline { 2 - 5 } & Pretest & Postest & Pretest & Postest \\
\hline Skor maksimum & 23 & 27 & 23 & 28 \\
\hline Skor minimum & 5 & 16 & 4 & 18 \\
\hline Skor rata-rata & 11,55 & 21,10 & 11,69 & 23,63 \\
\hline
\end{tabular}

Perbandingan capaian skor rata-rata kelas kontrol dan skor rata-rata kelas ekperimen ditampilkan pada gambar 2 berikut:

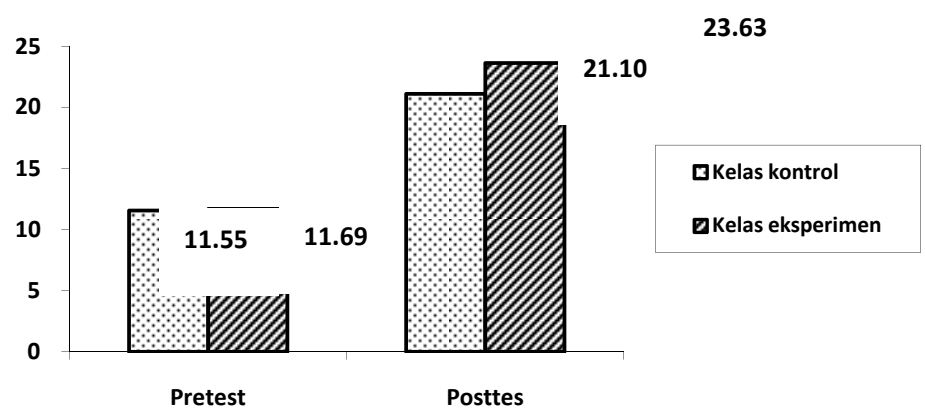

Gambar 2: Perbandingan capaian skor rata-rata kelas kontrol dan skor rata-rata kelas ekperimen

Gambar 2 menunjukkan adanya peningkatan dari skor pretest ke skor posttest yang menunjukkan peningkatan hasil belajar fisika siswa, baik pada kelas eksperimen maupun pada kelas kontrol. Kualitas peningkatan hasil belajar ini dipertegas dari hasil analisis $N$-gain berikut ini:

Tabel 8: Hasil Analisis $N$-gain kelas eksperimen dan kelas kontrol

\begin{tabular}{|l|c|c|c|c|c|c|c|}
\hline \multicolumn{1}{|c|}{ Sampel } & $\mathrm{S}_{\text {post }}$ & $\mathrm{S}_{\text {pre }}$ & $\mathrm{S}_{\text {maks }}$ & $\mathrm{S}_{\text {post }}-\mathrm{S}_{\text {pre }}$ & $\mathrm{S}_{\text {maks }}-\mathrm{S}_{\text {pre }}$ & $N$-gain & Kategori \\
\hline $\begin{array}{l}\text { Kelas } \\
\text { eksperimen }\end{array}$ & 23.76 & 12.03 & 28.00 & 11.73 & 15.97 & 0,7 & Tinggi \\
\hline Kelas kontrol & 21.28 & 11.91 & 28.00 & 9.38 & 16.09 & 0,6 & Sedang \\
\hline
\end{tabular}

Data capaian skor yang tercantum dalam tabel 7, selanjutnya dilakukan parasyarat yaitu uji homogenitas vairians dan uji normalitas distribusi data. 
Rekapitulasi hasil uji homogenitas dan uji normalitas pada taraf signifikansi 5\% ditampilkan pada tabel 9 berikut:

Tabel 9: Hasil uji homogenitas dan uji normalitas data

\begin{tabular}{|c|c|c|c|c|c|c|}
\hline \multirow{3}{*}{ Faktor } & \multicolumn{2}{|c|}{ Uji Homogenitas } & \multicolumn{4}{|c|}{$\begin{array}{c}\text { Uji } \\
\text { Normalitas }\end{array}$} \\
\hline & \multirow{2}{*}{$F_{\text {Hitung }}$} & \multirow{2}{*}{$F_{\text {Tabel }}$} & \multicolumn{2}{|c|}{$\begin{array}{c}\text { Kelas } \\
\text { kontrol }\end{array}$} & \multicolumn{2}{|c|}{$\begin{array}{c}\text { Kelas } \\
\text { Eksperimen }\end{array}$} \\
\hline & & & $\chi^{2}$ Hitung & $\chi^{2}$ Tabel & $\chi^{2}$ Hitung & $\chi^{2}$ Tabel \\
\hline Nilai & 1,187 & 1,81 & 9,27 & 11,07 & 0,18 & 11,07 \\
\hline $\mathrm{dk}$ & \multicolumn{2}{|c|}{$32 / 31$} & \multicolumn{2}{|c|}{5} & \multicolumn{2}{|c|}{5} \\
\hline Keputusan & \multicolumn{2}{|c|}{$\begin{array}{l}\text { Varian data } \\
\text { Homogen }\end{array}$} & \multicolumn{2}{|c|}{$\begin{array}{c}\text { Data terdistribusi } \\
\text { Normal }\end{array}$} & \multicolumn{2}{|c|}{$\begin{array}{c}\text { Data terdistribusi } \\
\text { Normal }\end{array}$} \\
\hline
\end{tabular}

Uji hipotesis menggunakan analisis anakova dapat dilakukan karena telah memenuhi syarat, yaitu data berasal dari sumber yang homogen dan data terdistribusi secara normal. Selanjutnya, secara ringkas hasil analisis anakova ditampilkan pada tabel 10 berikut:

Tabel 10: Hasil analisis anakova pada uji hipotesis

\begin{tabular}{|c|c|c|c|c|c|c|c|c|}
\hline \multirow{2}{*}{$\begin{array}{l}\text { Sumber } \\
\text { Variasi }\end{array}$} & \multirow[t]{2}{*}{$\mathrm{dk}$} & \multicolumn{3}{|c|}{$\begin{array}{l}\text { Jumlah Kuadrat-Kuadrat dan } \\
\text { Produk Silang }\end{array}$} & \multicolumn{3}{|c|}{$\begin{array}{c}\text { Disesuikan (Dikoreksi) } \\
\text { karena Regresi }\end{array}$} & \multirow[t]{2}{*}{$\mathrm{F}$} \\
\hline & & $X$ & $\mathrm{XY}$ & $\mathrm{Y}$ & $Y$ & $\mathrm{dk}$ & KT & \\
\hline $\begin{array}{c}\text { Perlakuan } \\
\text { Galat }\end{array}$ & $\begin{array}{r}1 \\
63\end{array}$ & $\begin{array}{r}149,50 \\
153748,44\end{array}$ & $\begin{array}{r}229,74 \\
301892,34\end{array}$ & $\begin{array}{r}681,68 \\
595706,55\end{array}$ & 2926,65 & 62 & 47,20 & \multirow{3}{*}{7,54} \\
\hline Total & 64 & & & & 3282,41 & 63 & & \\
\hline $\begin{array}{c}\text { Perlakuan } \\
\text { disesuaikan }\end{array}$ & & & & & 355,76 & 1 & 355,76 & \\
\hline
\end{tabular}

Dari tabel 10 dapat dilihat bahwa hasil analisis anakova diperoleh nilai $\mathrm{F}_{\text {hitung }}=7,54$, sedangkan nilai $\mathrm{F}_{\text {tabel }}$ dengan $\mathrm{dk}$ pembilang $1 \mathrm{dan} \mathrm{dk}$ penyebut 62 pada taraf signifikansi 5\% adalah 3,96. Karena $F_{\text {hitung }}=7,54>$ Ftabel $=4,00$, maka dapat disimpulkan Ho ditolak dan Ha diterima. Hasil analisis ini membuktikan bahwa bahan ajar fisika berbasis learning cycle efektif untuk meningkatkan hasil belajar fisika siswa.

Secara kualitatif keunggulan ini disebabkan karena beberapa faktor yaitu (1) bahan ajar yang digunakan sesuai dengan kebutuhan; (2) bahan ajar yang digunakan dapat memandu siswa belajar secara aktif dalam mengkonstruk pengetahuan dari pengalamannya; (3) bahan ajar memandu siswa belajar secara terstruktur melalui pengumpulan fakta, pengenalan konsep, dan aplikasi konsep; (4) bahan ajar memandu siswa dalam mengaplikasikan konsep yang telah dimiliki pada penomena-penomena dalam kehidupan sehari-hari dan penyelesaian soal yang bersifat kuantitaitf. Meningkatnya hasil belajar fisika siswa juga disebabkan karena bahan ajar yang 
digunakan dalam pembelajaran berbasis model yang memiliki kekhasan tersendiri yaitu siswa dapat membangun pengetahuan sendiri melalui berpikir rasional. Hal ini sesuai dengan pendapat Rustaman (2005), bahwa model pembelajaran learning cycle (sebagai basis pengembangan bahan ajar) merupakan model pembelajaran yang dilandasi konstruktivisme yang dapat mengembangkan struktur kognitif untuk membangun pengetahuan sendiri melalui berpikir rasional. Hasil penelitian yang telah diperoleh juga sesuai dengan penelitan yang telah dilakukan oleh Purwoko (2009), bahwa bahan ajar berbasis learning cycle secara signifikan dapat meningkatkan hasil belajar kimia siswa.

Pada akhir pertemuan implementasi bahan ajar di kelas ekperimen diberikan lembar observasi untuk memperoleh data kelayakan bahan ajar yang dikembangkan. Hasil pengisian lembar observasi kelayakan bahan ajar dapat dilihat pada tabel 11 dibawah ini:

Tabel 11: Rekapitulasi tanggapan pengguna terhadap bahan ajar fisika berbasis learning cycle .

\begin{tabular}{|c|l|c|c|l|}
\hline No & \multicolumn{1}{|c|}{ Aspek yang dinilai } & Rata-rata & Prosentase & Kriteria \\
\hline 1 & Isi & 4,22 & $84,4 \%$ & Tinggi Sekali \\
\hline 2 & Kebahasaan & 4,22 & $84,4 \%$ & Tinggi Sekali \\
\hline 3 & Penyajian & 3,93 & $78,6 \%$ & Tinggi \\
\hline 4 & Kegrafisan & 4,24 & $84,8 \%$ & Tinggi Sekali \\
\hline Rata-rata total & 4,15 & $83,0 \%$ & Tinggi \\
\hline Keterangan: & & \\
Skor berada pada interval 1 -5 & & \\
$4,20-5,00=$ Tinggi Sekali & & \\
$3,40-4,19=$ Tinggi & & \\
$2,60-3,39=$ Kurang & & \\
$1,80-2,59=$ Rendah & & \\
$1,00-1,79=$ Rendah Sekali &
\end{tabular}

Berdasarkan tabel 11 di atas dapat diperoleh gambaran bahwa pada aspek kelayakan isi memperoleh penilaian pada kategori tinggi sekali, aspek kebahasaan berada pada kategori tinggi sekali, aspek penyajian berada pada kategori tinggi, dan aspek kegrafisan berada pada kategori tinggi sekali. Secara keseluruhan bahan ajar fisika berbasis learning cycle mendapat penilain pada kategori tinggi, sehinggaa dapat disimpulkan bahan ajar fisika berbasis learning cycle layak digunakan pada proses pembelajaran fisika kelas XI IPA pada pembahasan matei pokok Teori kinetik gas dan Termodinamika. 


\section{Kesimpulan}

Berdasarkan penelitian dan pengembangan yang telah dilakukan, dapat disimpulkan bahwa:

1. Bahan ajar fisika berbasis learnig cycle 3E dikembangkan dari prototype bahan ajar melalui tahapan-tahapan:
a. Validasi ahli memperoleh penilaian baik dan beberapa masukan untuk perbaikan
b. Evaluasi dan perbaikan dilakukan dari masukan-masukan validator
c. Uji coba terbatas memperoleh tanggapan sangat baik dan beberapa masukan untuk penyempurnaan
d. Evaluasi dan penyempurnaan dilakukan dari masukan-masukan responden
e. Pengujian melalui implementasi pada skala yang lebih luas untuk menguji keefektifan dan kelayakan produk bahan ajar

2. Bahan ajar yang telah dikembangkan dengan karakteristik mengikuti sintaks model pembelajaran learnig cycle $3 \mathrm{E}$ yang terdiri dari tahap eksplorasi, tahap pengenalan konsep dan tahap aplikasi konsep.

3. Bahan ajar fisika berbasis learning cycle 3E yang dikembangkan layak digunakan pada pembelajaran fisika di kelas karena memiliki tingkat:
a. Kelayakan isi mencapai $84,4 \%$ dengan kategori sangat tinggi
b. Kebahasaan mencapai $84,4 \%$ dengan kategori sangat tinggi
c. Penyajian mencapai $78,6 \%$ dengan kategori tinggi, dan
d. Kegrafisan mencapai $84,8 \%$ dengan kategori sangat tinggi.

4. Bahan ajar fisika berbasis learning cycle $3 \mathrm{E}$ efektif dalam meningkatkan hasil belajar fisika siswa.

\section{Daftar Pustaka}

Depdiknas. 2008. Panduan Pengembangan Bahan Ajar. Jakarta: Direktorat Jendral Manajemen Pendidikan Dasar dan Menengah Direktorat Pembinaan SMA.

2007. Pedoman Umum Penyusunan Bahan Ajar SMA. Jakarta: Direktorat Pendidikan Menengah Umum

2007. Permendiknas RI No. 41 Tahun 2007 Tentang Standar Proses untuk Satuan Pendidikan Dasar dan Menengah. BSNP: Jakarta

Fikri. 2012. Penerapan Belajar Fisika Dengan Analogiuntuk Meningkatkan Hasil Belajar Fisika Siswa SMA. Unnes Physics Education Journal:Semarang 
Ghufron, Anik. 2005. Model Pengembangan Sistem Pembelajaran Bagi Penyiapan Sumberdaya Manusia Era Informasi. Yogyakarta: FIP UNY

Harjanto. 2007. Pengembangan Bahan Ajar untuk Peningkatan Kualitas Pembelajaran Program Pendidikan Pembelajar Sekolah Dasar. Didaktika, vol. 2 no.1 maret 2007: 216-226.

----------. 2005. Perencanaan pengajaran. Jakarta: Aneka cipta

Hernawan. 2010. Pengembangan Bahan Ajar. Jurusan Kurikulum dan Teknik Pendidikan: UPI

Mahardika. 2011. Pengembangan Bahan Ajar Mekanika untuk Meningkatkan Kemampuan Representasi Verbal, Matematis, Gambar, dan Grafik Mahasiswa Calon Guru Fisika. Disertasi. Bandung: Disertasi PPS UPI

Maryani. 2011. Pengembangan Bahan Ajar Berbasis Multimedia Interaktif Mata Kuliah Komputerisasi Akuntansi (Jurnal). Universitas Gunadarma.

Prastowo. 2011. Panduan Kreatif Membuat Bahan Ajar Inovatif Menciptakan Metode Pembelajaran yang Menarik dan Menyenangkan. Jogjakarta: Diva Press.

Purwoko, A. A. 2009. Pengembangan Bahan Ajar Berbasis Learning Cycle (CL) Untuk Meningkatkan Kemampuan Berpikir Abstrak dan Hasil Belajar Siswa (Laporan Hasil Penelitian Hibah Strategis Nasional). Mataram: Universitas Mataram.

Rustaman. 2005. Strategi Belajar Mengajar Biologi. Malang: Universitas negeri Malang

Sudjana. 2002. Dasain dan Analisis Eksperimen Edisi IV. Bandung: Tarsito

Sugiyono. 2010. Metode Penelitian Kuantitatif Kualitatif dan $R \&$ D. Bandung: Alfabeta. 2008. Statistika Untuk Penelitian. Bandung: Alfabeta.

Toto. 2012. Pengembangan Bahan Ajar Dasar Untuk Calon Guru Biologi. Bandung: Te _.. PPS UPI.

Trianto. 2008. Mendesain Pembelajaran Kontekstual (Contextual Teaching and Learning) di Kelas. Jakarta: Cerdas Pustaka Publisher. 